\title{
Designing a Framework for Employment-Growth Targeting in Nigeria
}

\author{
Adetunji Adeniyi, PhD (Corresponding author) \\ Tunji Adeniyi and Associates Limited, Lagos, Nigeria \\ www.tunjiadeniyi.io
}

Tel: 234-(0)-805-700-0700

\begin{abstract}
Received: December 28, 2020 Accepted: January 21, $2021 \quad$ Published: February 5, 2021
doi:10.5296/jad.v7i1.18401ＵRL: https://doi.org/10.5296/jad.v7i1.18401
\end{abstract}

\begin{abstract}
Unemployment in Nigeria has assumed disturbing proportions despite fifteen years of sustained economic growth outcomes between 2000 and 2014. This needs very urgent attention from policy makers since the problem has further resulted in other social vices like: armed robbery, kidnapping, political thuggery, pipe-line vandalisation, and social unrest.

Unfortunately, policy makers have approached the deep-rooted problems with only tactical and superficial methods. There has been no serious attempt to target employment based on the economic fundamentals; and, the interdependencies and the interconnectedness of the various sectors and the working of the economy.

Using Johansen co-integration, and applying Vector Error Correction Model (VECM) regression to time series sectoral economic data of Gross Value Added (GVA), employment, interest rate, wage rate, and inflation rate, collected from the National Bureau of Statistics (NBS) this study constructed a framework that policy makers can use to target growth and employment simultaneously.
\end{abstract}

Keywords: economic growth, employment, unemployment, targeting

\section{Introduction}

Unemployment has become a major and seemingly intractable socio-economic problem in Nigeria. Unfortunately, there seem to be no long-term strategic data-based approach to solving the problem. Policy makers often adopt tactical approaches in addressing the deep-rooted economic problem. Most often, they expect employment to be an automatic by-product consequence of some superficial policies, with no concerted attempt to target employment as done to other socio-economic variables like growth, inflation, inflation, and 


\section{Macrothink}

Journal of Asian Development

ISSN 2377-9594 2021, Vol. 7, No. 1

interest rate. This aberration has become evident in the incidences of growth without commensurate job creation.

Consequently, this study aimed at designing a framework for targeting growth and employment simultaneously.

\subsection{Literature Review}

\section{Theoretical framework}

The national output of an economy is produced by combining the factors of production, including labour. The demand function for labour can be derived by assuming a constant elasticity of substitution (CES) production functional form and estimating the marginal productivity of labour (MPL) equation to obtain the input of labour in a Cobb-Douglass production functional form as follows (Mkhize, 2015): -

$\mathrm{GVA}_{\mathrm{t}}=\mathrm{A}\left\{\alpha \mathrm{K}_{\mathrm{t}}^{-\rho}+(1-\alpha) \mathrm{L}_{\mathrm{t}}^{-\rho}\right\}^{-\eta /-\rho}$

where,

$\mathrm{GVA}_{\mathrm{t}}=$ Gross Value Added (sectoral output)

$\mathrm{K}_{\mathrm{t}}=$ Capital input

$\mathrm{L}_{\mathrm{t}}=$ Labour input

$\mathrm{A}=$ Efficiency parameter; $\mathrm{A}>0$

$\eta=$ Returns to scale parameter; $\eta>0$

$\alpha=$ Distribution parameter; $0<\alpha<1$

$\rho=$ Extent of substitution (between $\mathrm{K}$ and $\mathrm{L}$ ) parameter, $\rho>-1$, and related to elasticity of substitution; $\sigma=1 / 1+\rho$

The derivative of labour (i.e. marginal product of labour $\left(\mathrm{MP}_{\mathrm{L}}\right)$ ) from Equation (1) can be written as:

$\mathrm{dGVA}_{\mathrm{t}} / \mathrm{dL}_{\mathrm{t}}=\eta(1-\alpha) / \mathrm{A}^{\rho / \eta} \cdot \mathrm{GVA}_{\mathrm{t}}{ }^{(1+\rho) / \eta} / \mathrm{L}_{\mathrm{t}}{ }^{\rho+1}$

The above $\mathrm{MP}_{\mathrm{L}}$ equation is solved for the $\mathrm{L}_{t}$ variable in order to get the empirical labour (employment) demand function:

$\eta(1-\alpha) / A^{\rho / \eta} \cdot G V A_{t}^{(1+\rho) / \eta}=L_{t}{ }^{\rho+1}$

$\left[\eta(1-\alpha) / A^{\rho / \eta} \cdot \operatorname{GVA}_{t}^{(1+\rho) / \eta}\right]^{1 / \rho+1}=L_{t}$

$\mathrm{L}_{\mathrm{t}}=\left[\eta(1-\alpha) / \mathrm{A}^{\rho / \eta} \cdot \mathrm{GVA}_{\mathrm{t}}^{(1+\rho) / \eta}\right]^{1 / \rho+1}$

$\mathrm{L}_{t}=\left[\eta(1-\alpha) / \mathrm{A}^{\rho / \eta}\right]^{1 / \rho+1} \cdot \mathrm{GVA}_{\mathrm{t}}^{(1+\rho / \eta)(1 / \rho+1)}$

$\mathrm{L}_{\mathrm{t}}=\beta_{0} \mathrm{GVA}_{\mathrm{t}}{ }^{\beta 1}$

where, 
$\beta_{0}=\left[\eta(1-\alpha) / \mathrm{A}^{\rho / \eta}\right]^{1 / \rho+1}$

$\beta_{1}=(1+\rho / \eta)(1 / \rho+1)$

$\beta_{1}=1+\rho / \eta \cdot \sigma$

$\sigma($ elasticity of substitution $)=1 / \rho+1$

However, if we log-transform Equation (3) above, we obtain the following employment function:

$\ln \mathrm{L}_{\mathrm{t}}=\ln \beta_{0}+\beta_{1} \ln \mathrm{GVA}_{\mathrm{t}}$

$=\beta_{0}+\beta_{1} \ln \mathrm{GVA}_{\mathrm{t}}+\ldots \beta_{\mathrm{n}} \ln \mathrm{X}_{\mathrm{nt}}+\varepsilon_{\mathrm{t}}$

Robust as the neo-classical concept of aggregate production function may seem, it is a subject of criticisms by a group of scholars, particularly, in the so-called 'Cambridge Capital Theory Controversies' of the late 1960s and early 1970s (Felipe \& McCombie, 2005). Two major issues were raised; viz: -

1. The problem of comparability of units of measurement: the neo-classical aggregate production function is defined such that output has to be a value, rather than a physical, measure regardless of the unit of observation (Felipe \& McCombie, 2001); and,

2. The problem of aggregation. Walters (1963); Felipe and Fisher (2003); and, Felipe and McCombie (2005) opined that it does not make sense to sum inputs and outputs across industries (for example oil refinery and farming) and estimate a function that purports to represent technological parameters, such as the aggregate elasticity of substitution of this combined industry (Felipe \& McCombie, 2005).

However, Solow (1966) came to the defense of the macroeconomic aggregate production function, even though he felt that it was not entirely justifiable (Felipe \& McCombie, 2005). Solow (1966) submitted that "the aggregate production function is an 'illuminating parable', or a mere device for handling data, to be used so long as it gives good empirical results, and to be discarded as soon as it does not, or as soon as something better comes up" (Felipe \& McCombie, 2005). Wan (1971) also supported Solow when he argued that the functional relationship between output $(\mathrm{Q})$ capital $(\mathrm{K})$ and labour $(\mathrm{L})$ is an empirical law which is operationally meaningful, since it can be empirically tested (Felipe \& McCombie, 2005). In further support, Cobb and Douglas (1928) and Douglas (1948) found that the aggregate production function gives a good statistical fit, with the estimated output elasticities close to the factor shares.

\subsection{Methodological Review}

Several econometric and descriptive techniques were employed to determine the objectives of this study as were stated in the analysis of the objectives.

In investigating objective one, descriptive analysis was used. However, for estimating objectives two and three the elasticity of employment approach was employed. 


\section{Macrothink}

Two methods have been employed in literature to calculate the employment elasticity of growth. The first is the arithmetic method of estimating employment elasticity with respect to output. By this method, employment intensity is estimated by dividing the proportional change in employment by the proportional change in output during a specified period, usually one year as follows:

$$
\varepsilon=\frac{\left[\frac{L_{t}-L_{t-1}}{L_{t}}\right]}{\left[\frac{Q_{t}-Q_{t-1}}{Q_{t}}\right]}
$$

Where:

$\varepsilon=$ Employment elasticity of output growth

$L_{t}=$ Employment at period $\mathrm{t}$

$L_{t-1}=$ Employment at the period prior to period $\mathrm{t}$

$Q_{t}=$ Output at period $\mathrm{t}$

$Q_{t-1}=$ Output at period t-1

The numerator, is the proportional change in the aggregate or sectoral employment of labour, $\mathrm{L}$, between two time periods $\mathrm{t}$ and $\mathrm{t}-1$, and the denominator is the proportional change in aggregate output or sectoral gross value added in the same period.

The advantage of this approach is that it is very simple to estimate. However, it has some shortcomings. The first is that being a two-point estimation, the elasticity computed is not robust for the purpose of forecasting. The second defect is that the elasticity calculated may not present the technological relationship between labour and output for a sector or the state of technology in the economy, because the two years selected may not be representative. (Ajilore \& Yunisa, 2011).

The second methodology is the econometric regression analysis, where a functional form assumed between employment and output is estimated. This is specifically advantageous for long and reliable time series data on employment and output. This method is more reliable because of its forecasting capability and the avoidance of the problem of finding representative base and terminal years (Lim, 1976).

Despite its relative usefulness, employment elasticity has its own shortcomings in that it may not perfectly explain the growth-employment nexus for some reasons. The first problem is that of reverse causality between employment and output. At the aggregate level, the combination of labour and other factors of production produces aggregate output. Consequently, the rate of growth of output is positive correlate of the rate of employment. All things being equal, the faster the growth of labour the faster the growth of output. By implication, employment intensity concentrates only on the demand side of the functional specification and does not consider the supply side, the output producing effect of the employment of labour. The second defect is that employment intensity holds only for a given state of technology. Thirdly, the concept of employment intensity is a function of the 
prevailing policy regime. A given policy regime could be more or less conducive to the growth of employment and could either be labour-intensive or capital-intensive (Islam \& Nazara, 2000).

Obviously, the intensity of employment is not an explanatory variable. It is essentially endogenous and a consequence of many factors. It is a function of the natural forces of market economy and the historical configurations of existing policies, the two effects of which are intertwine and difficult to disaggregate.

Another issue in estimating employment intensity is that concerning the assumption that economic growth will enhance employment growth while economic recession will cause unemployment. This is not necessarily the situation, as discovered by Islam and Nazara (2000) because of the "unemployment as luxury" hypothesis. The proposition is that if and when there are no unemployment benefits, unemployment during economic recession may become a luxury, such that people respond by re-allocating their services to the agricultural and the informal sectors rather than remaining "openly unemployed." When this happens, unemployment becomes a luxury that only those with adequate non-labour income can afford.

Furthermore, there is the criticism that aggregate employment intensity may not be able to compute the net effect of economic growth on sectoral employment.

However, two key considerations nullify the above criticisms and make employment intensity, as a concept robust enough to explain the nexus between economic growth and employment of labour. First, there exists a relatively stable relationship between aggregate employment and economic growth in the developed world useful in identifying growth thresholds at which employment generation becomes important. Second, employment intensity recognises the differences between a movement along a given employment-GDP growth curve and the shift of the curve.

Hence, at any point, the calculated employment intensity will measure the gradient of the curve. The gradient and intercept of the curve will also change based on the behaviour of the shift parameters, which in themselves are important dynamic factors like in technology and policy regimes. Since such shift variables cannot be readily captured and fed into the estimation of the intensity of employment, it is important to update the estimates on a regular basis. Such a procedure will also alert policy makers to any significant changes in the employment generating capacity of the economy and the need for policy action. Therefore, Islam and Nazara (2000) made of different time periods for computing employment intensity for the purpose illustrating this.

Furthermore, for disaggregating the influence of sectoral gross value added and total GDP on employment, Islam and Nazara, (2000) computed estimates that are sensitive to this distinction. They also prescribed the use of several methodologies and data sets from different sources to compute the estimates. This in itself will serve as a sensitivity analysis of the robustness of the of the methodology.

Consequently, this study shall employ the second method of regression analysis for the 
estimation of aggregate elasticity and sectoral elasticities of employment.

\subsection{Empirical review}

Dopke, (2001) reviewed past work and the empirical results on the employment elasticity of growth in selected developed countries and concluded that the nexus between unemployment and growth was still stable in the nineteen-nineties. However, the outcome of cross-country and panel studies suggest that the employment elasticity of output expansion is influenced by the country's wage setting mechanism, the share of the service sector, and labour market flexibility.

Oloni, (2013) investigated the effect the economic growth in Nigeria had on employment creation using Johansen Vector Error Correction Model. The findings revealed that, although economic growth had positive relationship with employment, the relationship was not significant.

Sodipe and Ogunrinola (2011) investigated the influence of economic growth on employment using time series data. Ordinary Least Square (OLS) regression model was employed to analyze the data. The result revealed that economic growth impacted positively and significantly on employment. However, a negative and significant relationship between aggregate employment growth rate and the Gross Domestic Product growth rate was observed.

The story is not too different elsewhere in Africa. According to Page, (2012), Africa has experienced fifteen years of consistent economic expansion. Income per capita for the region as a whole rose steadily, and regional growth exceeded the world mean. In the last decade, six of the globe's ten fastest growing economics were in Sub-Saharan Africa. However, this good growth performance has not given rise to strong growth of "good" jobs (that is, those paying higher wages and providing better working conditions) especially for young people.

He argued that Africa's unemployment malaise is symptomatic of its lack of structural change. Instead, since 1990, structural shift has been to the wrong direction, with labour moving from higher to lower productivity employment. This phenomenon is also now common in Nigeria, whereby farmers abandon their farms to engage in motor cycle (okada) transportation business.

As a result, he submitted that employment policies should not concentrate only on the supply side of the labour market. While labour market reforms and active market policies can help in tackling the employment issue, the most important achievement will most likely come from policies designed to promote the growth sectors with high labour productivity from a strategy for structural change.

Following the computation and compilation of the current and future structure of employment in Sub-Sahara Africa (2005-2020) based on household survey estimates for 28 countries and an elasticity model that explored the relationship among aggregate employment, economic growth and demographic outcomes, Fox, Haines, Munoz and Thomas (2013), found that Agriculture continued to employ majority of the labour force, although labour is shifting 


\section{MInstitute Macrothink $^{m}$}

gradually out of the sector. Sub-Sahara Africa's projected rapid labour force expansion, combined with a low baseline of private sector wage employment, implies that even if Sub-Sahara Arica attains another decade of strong economic growth performance, the share of labour force employed in private enterprises is not projected to rise substantially. Governments would, therefore, need to execute strategies to attract private enterprises that provide wage employment, but they also need to improve productivity in the traditional and informal sectors which are projected to continue to employ the largest proportion of the ever expanding labour force. The above agrees with the earlier conclusions reached by Page, (2012). What this suggests is that policy makers in Sub-Sahara Africa have to find creative ways to retain the pivotal role of Agriculture and its value chains in providing many and quality jobs.

In examining the effects of the recent outbreak of Ebola Virus on the economy of West Africa through the trade channel, Adegun, (2014) exposed the nexus between fall in GDP and unemployment which moved in the same direction. He opined that the Ebola virus has resulted in movement restrictions and high mortality rates. This has in turn, evolved into less trade across borders and inside countries. This manifests in lower income and reduced productivity of firms, household, and farmers, leading in turn to reduced private savings and government revenue. This further results in declined national savings, capital accumulation and investments, unemployment, and ultimately fall in GDP growth to complete the vicious cycle.

In Ghana, employment expansion trails economic growth due to high growth of low employment creating sectors against slow growth of economic sectors with high labour absorption capacity (Baah-Boateng, 2013). In a cross-sectional estimation of a probit regression which indicated a strong effect of demand factors on unemployment this indicates a weak employment creating effect of economic growth. He discovered higher vulnerability of youths and urban dwellers. Educational attainment and gender also explain unemployment in some cases, while reservation wage also have significant and rising influence on unemployment. He proffered three recommendations; namely: (a) policies that promote investment in agriculture and manufacturing which are associated with higher employment intensity of output (b) targeted intervention for youth employment, including support for entrepreneurial training and start-up capital to attract young school leavers to become "creators" rather than "seekers" of job; and (c) a downward review of reservation wage expectation on the part of job seekers.

In Liberia, expectedly, growth slowed down considerably to an estimated 1.8 per cent in 2014 from $8.7 \%$, in 2013 due to the advent of the Ebola virus malaise, which had severe impact on economic and social activities. Some of government short-term priorities were to support the Ebola-affected households in improving income and employment while it intends to improve the business-enabling environment to create employment in the longer term. On the supply side, educational reforms would be introduced to generate skilled work force.

In Cameroon unemployment is low in the strict sense of the term at $4.4 \%$. In the broad sense, it is about $13 \%$. This does not include underemployment put at about $75.8 \%$. Furthermore, 


\section{MInstitute ${ }^{\text {Macrothink }}$}

the informal sector is large and accounts for about $90 \%$ of the employed labour force. As a result, government made employment an important element of development policy. Government has included unemployment as one of the three strategic components of the Growth and Employment Strategy Paper (GESP), thus considering employment not only as a consequence of economic growth but also as a promoting factor of such growth. Consequently, government is tackling unemployment through three key approaches; namely: (i) increasing quality employment opportunities (ii) matching the demand to the supply of labour, and, (iii) improving the efficiency of the labour market (IMF, 2010).

In examining employment problems in East Africa, using Tanzania as a case study, Nangale, (2012) observed that the high (5-8\%) GDP growth rates in Tanzania was not followed by expanded employment generation, particularly for the frequently disadvantaged group, such as the youth. As a consequence, there is unemployment and underemployment among the youth population. He concluded that increased economic growth, though necessary, is not a sufficient condition for increased employment creation, particularly for young people. He identified gaps in the performance of the labour market and in the implementation of the national employment policy. To tackle unemployment, he recommended the removal of the following labour market barriers: mismatch between job and skills; inadequate job matching; poor signaling, poor information systems; lack of tax cut incentives to employers; lack of access to capital and existence of financial and investment policies which are insensitive to solving the problem of unemployment.

In Kenya, Omolo, (2010) found that formal sector employment continued to lag behind economic expansion, whereas, the rate of employment growth in the informal sector, so called Jua Kali, has continued to outstrip economic growth rate. As at 2008, the Jua Kali sector accounted for $80.5 \%$ of employment, rising from only $20.6 \%$ in 1986 . Between the two periods, Kenya economy grew at an average annual rate of $3.52 \%$, while the average rate of growth in formal sector employment was a low of $2.23 \%$ per annum, and the informal sector employment average growth was a high of $17.22 \%$ per annum. The data showed a transitioning of jobs from formal into informal sectors, moving from less than $25 \%$ of total jobs in the country in 1986 to slightly more than $80 \%$ of aggregate employment in 2008 . The accelerated expansion in informal employment occurred when the Kenya labour market started to undergo formal sector employment losses initiated by liberalisation polices, and the implementation of government strategy towards the promotion of growth and development of the informal and Jua Kali sectors, among other factors.

Malunda, (2012) employed Shapley decomposition methodologies to investigate the employment elasticity of economic growth in Rwanda in order to advise government on which sectors of the economy have a higher potential to create productive off-farm employment that will drive a greater percentage of the population out of poverty. He found that the percentage of the work force engaged in the manufacturing sector expanded by an average of $4 \%$ per annum and that these lags behind job growth in other sectors of the economy like construction, commerce, and transport, whose employment growth were well above $6 \%$. He advocated the empowerment of medium to large scale entrepreneurs by providing access to capital, particularly to the agro-processing industries in the rural districts. 
He further advocated investment in the utilities like power to support business.

According to Siphambe, (2007), Botswana has experienced good economic growth performance since independence in 1966. While formal employment grew almost in line with GDP until 1991, employment growth detached from output growth in the early 1990s. This divergence was found to have occurred during the introduction of a number of policy reforms intended to deregulate economy. From 1980 to 1991 the economy expanded at an average of $10.3 \%$ per annum but slowed down to $6.3 \%$ per annum between 1991 and 2005 . However, the fall in employment rate was steeper from $9.1 \%$ to $2.2 \%$ in the respective periods. Consequently, despite the good growth regimes, Botswana still had high unemployment and a growing informal sector. This has been traced to the non-diversified mono-cultural economy, which rely almost exclusively on the extraction of diamond. Besides, the slowdown in employment growth also coincided with the implementation of reforms (financial liberalisation and labour market deregulation) intended to liberalise the economy and reduce direct government involvement.

Ajilore and Yinusa (2011) reached similar conclusions as above on the Botswana economy when they investigated the employment elasticity of sectorial output growth. They used both simple elasticity and econometric-type methodologies to investigate empirical evidence on the impact of economic growth on sectoral employment in Botswana. They discovered the low labour absorptive capacity of the Botswana economy at the aggregate and at sectoral levels, suggesting that the growth performance in the country was job-insensitive. They prescribed a diamond-led economy which should diversify into sectors and activities that will employ more labour.

Temitope (2013) used the approach of causality of time series data when the order of integration of the series under investigation is different to examine the direction of causality between employment and economic growth in South Africa, using quarterly data from the first quarter of 2001 to the third quarter of 2012. He discovered that there was unilateral influence running from economic growth to employment. It was thus concluded that economic growth had a positive and significant influence on employment in South Africa over the period of study.

Soto, (2009) used a methodology of Co-integration Error Correction Model to decompose the effect of GDP growth, real wages, cost of capital and the real exchange rate on employment in Ecuador. The result show that a permanent expansion of 1\% in GDP growth led to an increase in employment of about $2.3 \%$ and the demand for labour was negatively related to increase in minimum wages and the cost of imported intermediate factor.

In sum, from the above literature review, it is obvious that the relationship between economic growth and employment, and the responsiveness of the transmission mechanism between them are country and time specific, depending on many factors such as the structure of the economy, labour market efficiencies, the state of technology and its rate of change, among other factors. The above review, also, reveals that employment in most economies is a function of wage rate, interest rate, and inflation rate. Regarding the structure of the economy, there exists many dimensions. It is not limited to the economic sectors as classified by 
UNSTAT alone. It is also a function of the relative sizes and the rate of change of the formal and informal sectors - formality and informality. It is equally a function of the duality that exists between the rural and urban sectors; and of the relative sizes and the rate of transition between the production and services sectors of the economy. However, there seem to be no specific relationship established between economic growth and employment nexus in the agricultural and non-agricultural sectors.

\subsection{Conceptual Framework}

\section{The concept of economic growth}

Economic growth usually manifests in an increase in a country's Gross Domestic Product (GDP). According to the National Bureau of Statistics (2014), Gross Domestic Product is the total monetary value of all the legitimate final goods and services produced by the country over a specific period, usually one year. Nigeria in 2014 rebased its GDP from 1990 to 2010. This new basis of national accounting resulted in an $89 \%$ increase in the estimated size of the economy. Consequently, Nigeria now has the largest economy in Africa, with an estimated nominal GDP of USD 510 billion, surpassing South Africa's USD 352 billion as at the year ended 2014. The exercise further showed that the Nigerian economy was actually more diversified than previously recorded. However, rebasing only provides up-to-date statistics (PriceWaterCoopers, 2015). It does not represent increase in productivity or increase in real output.

It is important that GDP is calculated accurately and up-to-date to enhance comparability among countries (PriceWaterCoopers, 2015). A recent comparison of the tax revenue-to-GDP of Nigeria to other countries, for example, supports GDP rebasing by Nigeria. According to PriceWaterCoopers (2015) the tax-to-GDP ratio compares the amount of tax collection to the nominal GDP. Generally, the ratio in poor countries is around half of what obtains in developed nations. The 2012 data stand at 44.6\% for France; Sweden, 45.6\%; UK, 39\%; US, 27\%; Tanzania, 12\%; and, Burkina Faso, $11.5 \%$. If we consider all the three tiers of government, Nigeria had about $14.6 \%$ and $7.8 \%$ before and after rebasing respectively (PriceWaterCoopers, 2015). Furthermore, accurate and current data will make planning, implementation, monitoring, and evaluation of programmes more robust and informed.

Economic growth is usually estimated in real or inflation adjusted terms, in order to remove the potential distortion ascribable to inflation on the prices of goods and services produced. Consequently, economic growth is the increase in the inflation adjusted market value of all legally recognised finished goods and services produced by an economy over time. It is measured as the percentage rate of increase in real GDP. One of the notable observations of the rebasing exercise in Nigeria is the fact that it has resulted in lower estimates of real GDP growth rates compared to previous estimates (NBS, 2014).

\section{The concept and measurement of unemployment and underemployment rates}

In Nigeria, according to NBS (2015), unemployment is an estimate of the number of people actively looking for job as a percentage of the labour force. The labour force population consists of all persons in the age bracket of 15-64 years. Consequently, unemployment, 


\section{Macrothink}

includes persons in the age bracket of 15-64 who, in the period under reference, were available for work, actively seeking for work, but were without work.

Underemployment, on the other hand, occurs if a person works less than forty hours, but work more than twenty hours, on the average a week and / or if he or she works forty hours but he or she is engaged in an activity that underutilises his or her skills, time, and educational qualifications.

Types of unemployment

Various types of unemployment have been identified in literature, viz: disguised unemployment, cyclical unemployment, seasonal unemployment, structural employment and frictional employment. Nigeria has all cocktail of unemployment types represented (Kayode et al., 2014).

Disguised unemployment shows up in large scale urban unemployment and underemployment. Underemployment is when people work for less than 40 hours, but more than 20 hours a week. Nigeria has a very low rate of capital formation. Furthermore, inadequate power supply and other weak productive infrastructure, and insecurity, have combined to deny Nigeria the opportunity of foreign direct investment (FDI) as a supplement to domestic capital formation. Inadequate access to and high cost of debt capital have limited investment and employment.

Seasonal unemployment is prevalent in rain-fed agriculture, whereby farmers become unemployed off-season. Irrigation would help reduce this because it will facilitate multiple crops per annum, keeping the farmers busy all year round. Cyclical unemployment has resulted from the bouts of recession that has led to job losses and lay-offs. The resultant low aggregate consumption further depresses the employment generating capacity of the economy.

Nigeria is also experiencing long-term or structural unemployment arising from sectoral transitioning from production to services, and frictional unemployment, due to immobility of labour, knowledge gap and the un-employability of job seekers. 


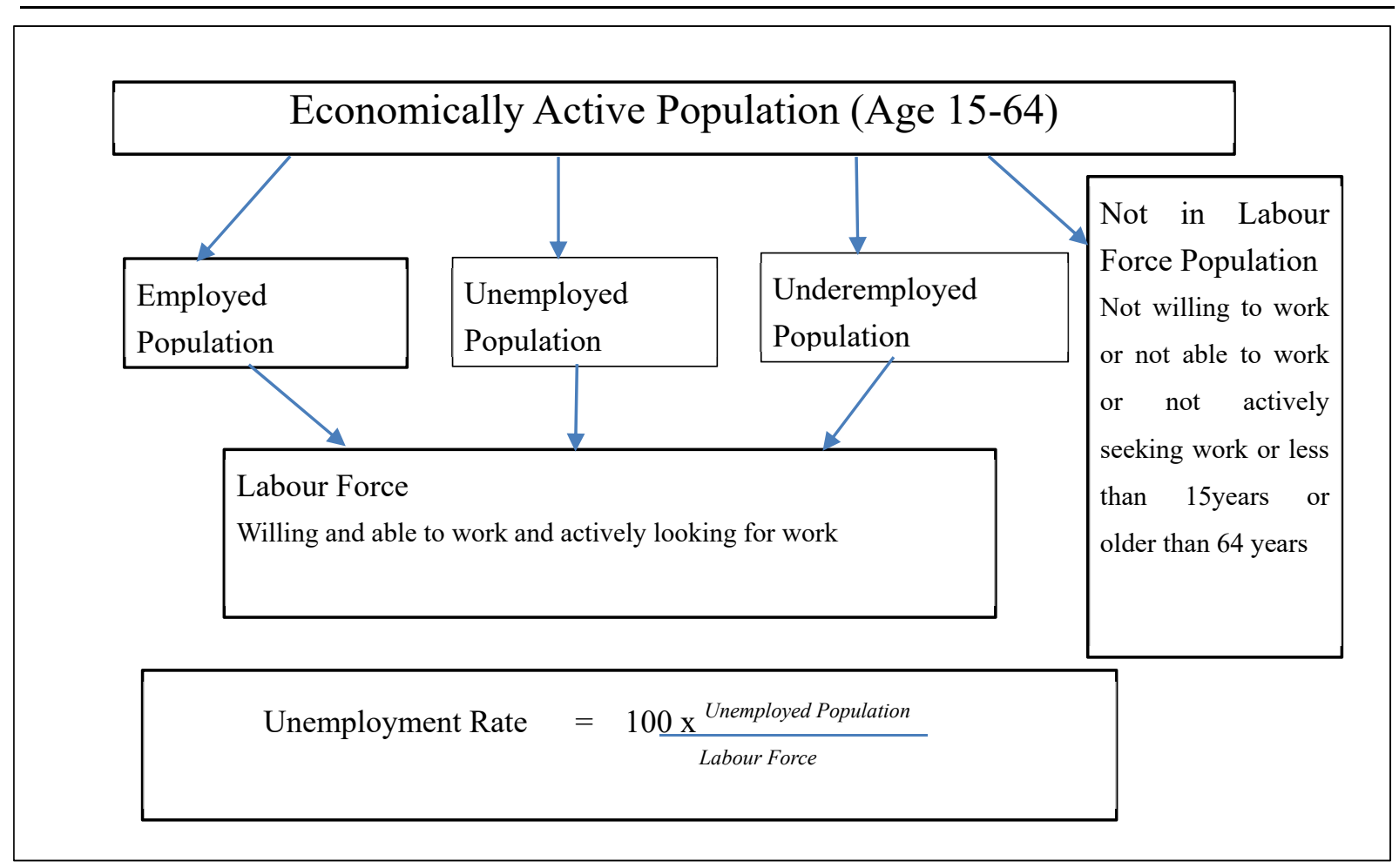

Figure 2.4.1. Computation of Unemployment rate

Source: NBS (2015: Q2). Employment / Underemployment Watch.

\section{The Relationship Between Output Growth and Employment}

According to Ajilore and Yinusa (2011), the principal link through which the poor benefits from economic growth is in the amount of employment it creates. Economic growth is necessary, particularly as the population grows, to provide job for those seeking to work. In an economy with low or no job intensity of growth, unemployment remains stubbornly high even when the economy is growing. Therefore, a major interest of economic policy is to improve the employment generating capacity of growth. This was the reason why Revenga and Bentolila (1995) submitted that a determination of the sources of cross-country differences in the Okun relationship would be useful for macroeconomic policy. Consequently, over the years, researchers studied the relationship between economic growth and employment. Early studies by Okun $(1962 ; 1970)$ defined the popular Okun's coefficient which measures the rate of change of real output for a given change in unemployment rate. Okun's law has its origin in Keynesian economics.

Okun's law has attracted tremendous attention from researchers for various reasons. First, it can be tested empirically (Jibril et al., 2015). Second, it is important as a macroeconomic building block and also a useful proxy. For example, when combined with Phillips curve, it produces the aggregate supply curve (Prachowny, 1993). Thirdly Okun's law has applications in macroeconomic policy, especially, in determining the optimal or desirable growth rate, and as a prescription for reducing unemployment. Okun's coefficient is a useful "rule-of-thumb" in forecasting and policy making (Silverstone \& Harris, 2001). 
Baker and Schmitt (1999) estimated Okun coefficient for a panel of OECD countries and found that the employment intensity of growth today is higher than in the sixties. They stressed the importance of export growth as a determinant of domestic employment. They also concluded that the relatively good empirical performance of Okun equation implies that macroeconomic forces play a greater role in explaining unemployment than is generally believed.

Grounded as the Okun's law may appear, it is not without its own shortcomings. It has drawn the criticism of researchers, first from Okun (1970) himself, when he observed that his 1:3 relationship masked the effect of changes in other factors that accompany employment growth to foster economic growth. Okun's law had specified that an increase in the economic growth rate by $3 \%$ is expected to reduce the unemployment rate to $1 \%$. point.

Another concern investigated in literature is the consistency of the Okun's law across time and space. According to Dopke (2001) the relationship between growth and employment may be altered with the passage of time due to changes in technology, changes in the institutional arrangements in the labour market and or changes in wage policies. Aside from inter-temporal instability, the link between growth and employment may also vary across geographies. In this regard, according to Pini (1997), employment intensity in Germany and Japan ascended between 1979 and 1995 compared to 1960 -1979. In contrast it declined in Sweden and France, whereas it exhibited only little change in Italy, the UK and US. Pini (1997) also discovered negative employment intensity between 1990 and 1995 in Sweden and Italy. Furthermore, the relationship between output and unemployment is asymmetric contrary to the specification of Okun. Output expansion and contraction are accompanied by different changes in unemployment (Lee, 2000; Silverstone and Harris, 2001; Viren, 2001; Dopke, 2001; Cauresman, 2003; Silvapulle, Moosa, \& Silvapulle; 2004).

On their own part, Khan (2001), Kapsos (2005), and Islam (2004) observed that employment intensity of growth has over emphasised employment growth over productivity growth. While employment growth emphasises the number of jobs created, productivity growth emphasises the qualitative aspect of growth in terms of the number of "decent jobs". Consequently, both the employment elasticity of growth and the productivity intensity of growth are needed to achieve economic development objectives, such as poverty targeting.

Furthermore, some researchers criticised Okun's law for neglecting, in its specification, the effect of relative prices (Flaig \& Rottman, 2000); institutional factors (Revenga \& Bentotila, 1995 ) and of exchange rate volatility (Buescher \& Muller, 1999).

They found that the employment elasticity of growth is strongly related to real labour cost, exchange rate volatility and labour market institutions.

In Nigeria, employing the methodologies of Engle Granger co-integration test and Fully Modified OLS on 1980-2008 annual time series data, Bankole and Fatai (2013) discovered that Okun's law did not hold. 


\section{Al Macrothink}

\section{Concept of Labour Market}

The structure and operations of the labour market in any economy is very important. The market determines vital economic outcomes of aggregate output and growth in the economy. Consequently, for good economic performance and social welfare, it is important that the labour market, like any other factor market, functions efficiently. Unfortunately, however, the operations of the labour market is influenced by many structural factors, institutional and regulatory, that limit its efficiency (Folawewo, 2015).

Institutional and regulatory arrangements in the labour market, such as trade unions, associations, bye-laws and judicial measures that govern hiring, firing, collective bargaining process, and other labour market activities have implications on efficiency of market functions of employment, wage determination, and productivity, among others. Furthermore, the nature and structure of the labour market, such as the extent of formality and informality affects its functioning and the effectiveness of its institutions (Sanchez-Puerta, 2010; Folawewo, 2015).

The desirability of labour market institutions and regulations, according to Folawewo (2015) is to manage market failure which often lead to inefficient allocation of resources. Consequently, the institutions and regulations help to ensure optimality and to protect workers. Unfortunately, contrary to their objectives, they often bring about unintended and undesired effects on labour market. In Nigeria, even though they have been set up in line with the standards of the International Labour Organisation (ILO) of which Nigeria is a member, labour market institutions and regulations are weak and often do not effectively serve the purposes for which they were established - the establishment and protection of workers' right, protection of the vulnerable workers, enforcement of minimum wage, compensation, and the provision of minimum working conditions (Folawewo, 2015).

The Nigerian labour market is dominated by self-employed persons, followed by wage and salary earners. According to Ogwumike, Alaba, F., Alaba, O., Alayande, and Okojie (2006), self-employed persons (farmers, traders and others) accounted for about $54.9 \%$ and wages and salaries (private and public) component for $38.7 \%$ of employed persons. Together, these two sectors of employment accounted for $93.6 \%$ of employment in the economy (See Table $3)$. 


\section{Macrothink}

Labour Market Structure in Nigeria According to National Manpower Board

\begin{tabular}{|l|l|l|l|l|}
\hline Structure & Both Sexes \% & Males \% & Females \% & Females as \% of both sexes \\
\hline Employer & 4.3 & 5.3 & 2.7 & 25.1 \\
\hline Self Employed (Farmer) & 6.5 & 7.0 & 5.7 & 34.4 \\
\hline Self Employed (Trader) & 29.1 & 20.7 & 42.0 & 56.8 \\
\hline Self Employed (others) & 19.3 & 22.4 & 14.4 & 29.4 \\
\hline Emp. Wages \& Sal. (Private) & 18.6 & 22.0 & 13.4 & 28.3 \\
\hline Emp. Wages \& Sal. (Public) & 20.1 & 20.3 & 20.0 & 39.0 \\
\hline Paid Apprentice & 2.1 & 2.3 & 1.8 & 33.6 \\
\hline Total & 100 & 100 & 100 & 39.3 \\
\hline
\end{tabular}

Source: Ogwumike, Alaba, F., Alaba, O., Alayande, and Okojie (2006) P4.

From the above table, employers were accountable for only $4 \%$ of aggregate employment. Traders constituted the bulk of self-employed workers. They are responsible for $29.1 \%$ of aggregate employment. Other segments of the self-employed were responsible for about $19 \%$. Farmers were responsible for only $6.5 \%$ of aggregate employment. The public and private sectors provided employment for $20.1 \%$ and $18.6 \%$, respectively, of wage and salary earners. The paid apprentices were responsible for $2.1 \%$ of aggregate employment. Female employment was only very prominent among self-employed traders, where they constituted $57 \%$ of employment in the category. Their contributions in other areas were small and below those of their male counterparts. For example, they made up 39\% of total workers in the public sector, particularly, in the wages and salaries category and $28.3 \%$ of the private enterprise employees. Their shares of employment were, respectively, $29.4 \%$ and $34.4 \%$ for other unspecified self-employed and self-employed farmers. 


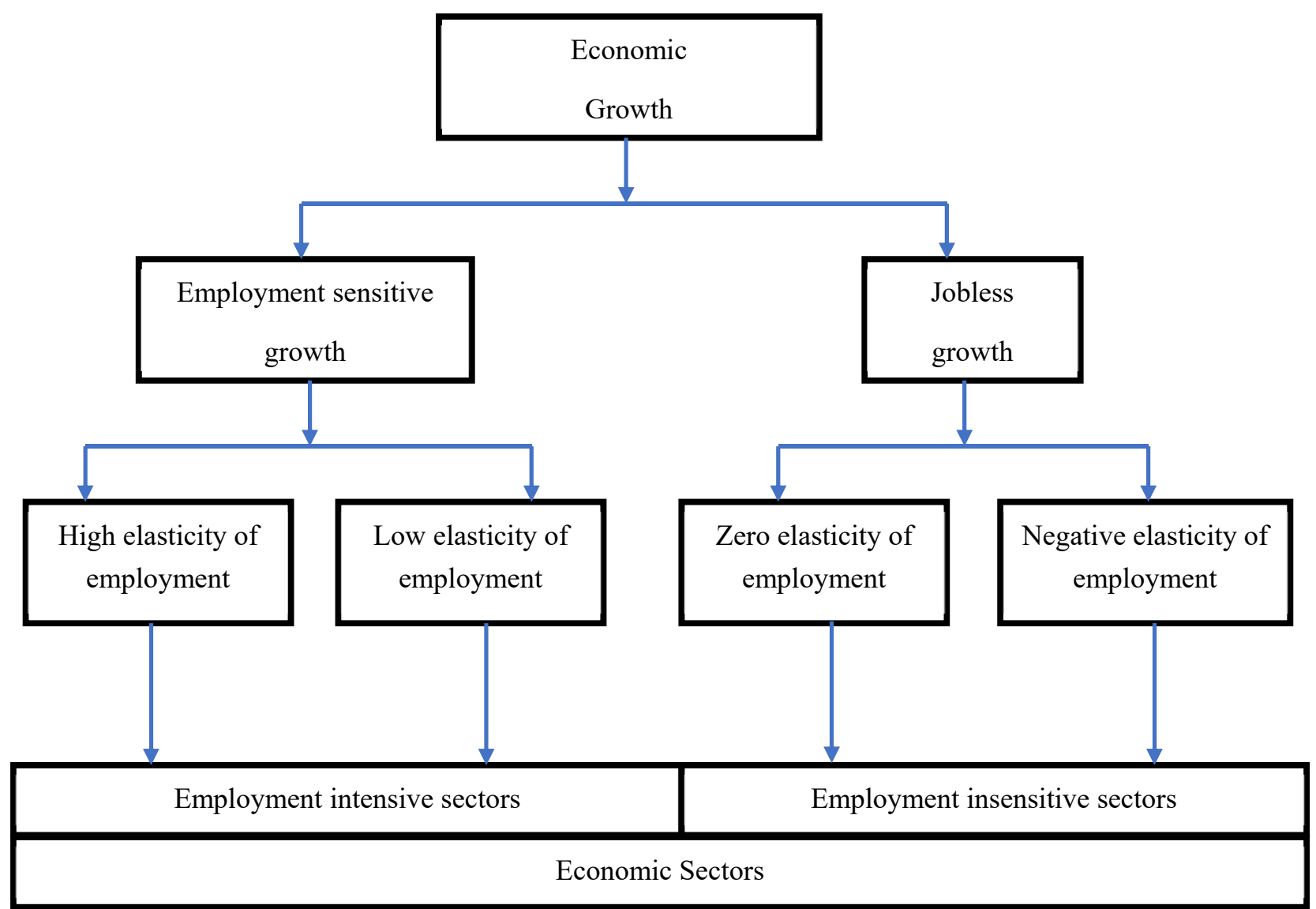

\section{Impact Pathways.}

Source: Author's Conceptualization.

\section{Modelling the theory of change}

Economic growth could either be employment intensive or "jobless." When it generates employment, the elasticity of employment could either be low or high. Naturally, not all sectors of the economy will produce employment intensive growth at the same rate. Furthermore, some other sectors will be employment insensitive outrightly. In some extreme cases, sectorial output growth could even come with job losses if the growth results from increased productivity occasioned by the substitution of labour-saving capital-intensive technologies for labour-intensive production processes.

Figure 3 represents the conceptualisation of the possible outcomes of the impact of growth on employment

\section{Methology}

Time series secondary data covering 1981 to 2014 on the rebased Gross Domestic Product (GDP) and sectoral Gross Value Added (GVA) at 2010 constant basic prices, employment, wage rate, inflation rate and interest rate were collected from the National Bureau of 


\section{Macrothink}

Journal of Asian Development

ISSN 2377-9594 2021, Vol. 7, No. 1

Statistics and Central Bank of Nigeria on agricultural sector. Similar data were collected on non-agriculture sectors of mining, manufacturing, trade and services, administration, and construction from the same sources. The variables were extracted from statutory publications of the institutions, collated and summarised into a table of data. The unit root test was carried out to test for stationarity of variables. A system of six employment equations was defined for employment in the economy. These were analysed using Vector Error Correction Model (VECM) regression at $\alpha_{0.05}$.

\section{Findings and Discussions}

A beauty of the Vector Error Correction Model analysis is that it enables a simultaneous modeling and analysis of all the sectors of the economy at the same time. This is similar to the real working of the economy, whereby all the sectors are at work at the same time to produce a unique set of economic outcomes like growth and employment. The series on the trade and and services sector were not stationary. Hence, it was excluded from the regression. Also, the regression results obtained from the construction sector were not significant. Hence, it did not make the dashboard, leaving only four major sectoral groupings for the framework.

Following from the above analysis, and the regression outcomes at the appendix, the study constructed a framework for employment-growth targeting as presented in the table below: 


\section{A framework for employment-growth targeting}

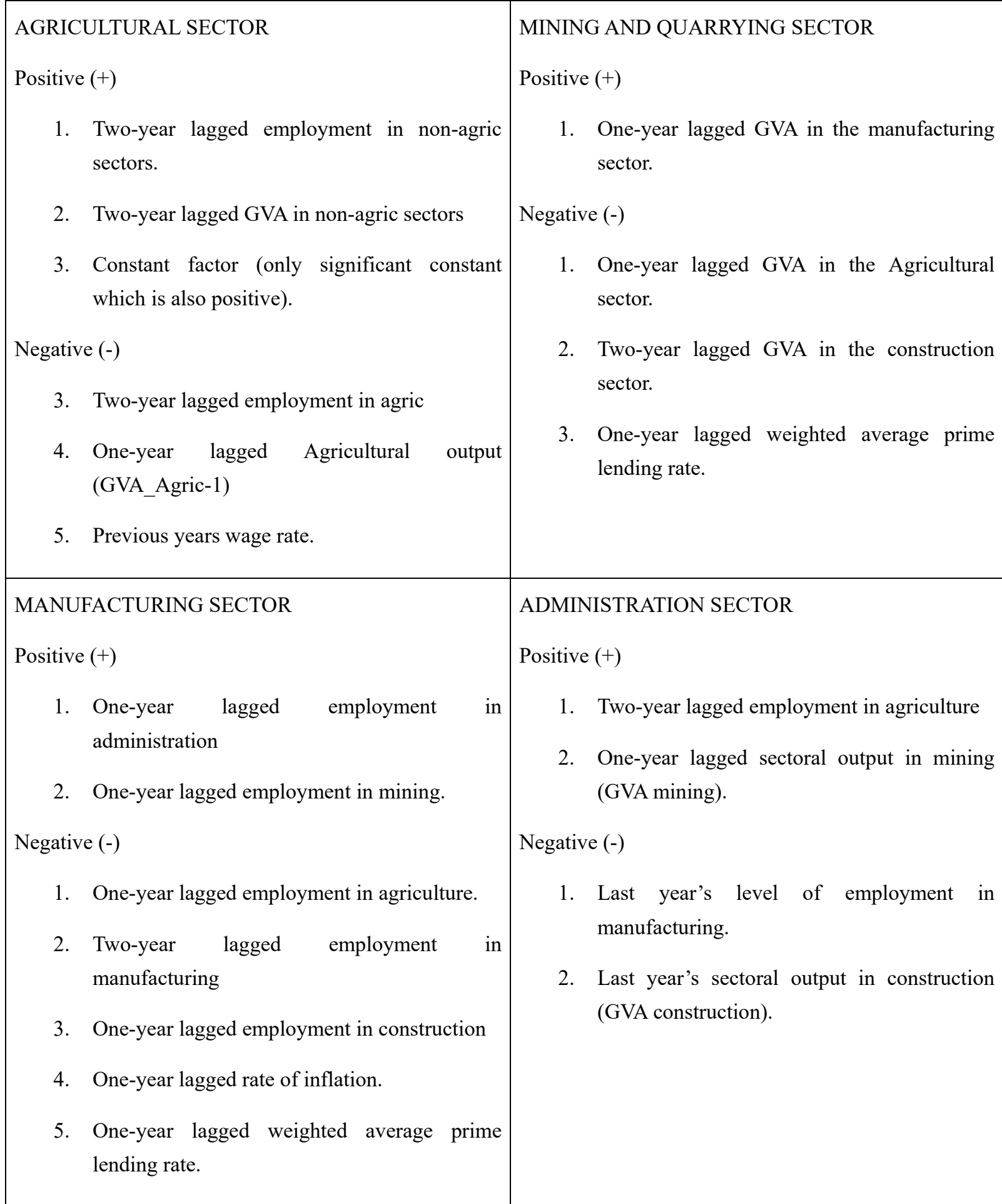

Source: Author's Analysis of Data collected from the National Bureau of Statistics

The above table paints a one pager dashboard which can be used to target employment or unemployment in the economy. In Nigeria, as in most African countries, we do not target unemployment or employment rate. Instead, governments expect unemployment to "reduce" 
as a by-product of some uncoordinated economic decisions in their annual budgets and Medium Term Expenditure Frameworks (MTEFs) unlike some other macroeconomic variables, such as average exchange rate, average inflation rate, and GDP growth rate.

Employment or underemployment issue should be kept in permanent focus, particularly, as it has become a prominent socio-economic malaise. Furthermore, in Nigeria, there is the need to achieve inclusive and sustainable balance economic growth in the wake of the strong desire to diversify the productive base economy.

The above table indicates that growth-employment targeting is not a short-term exercise. It is a complex, intertwined, inter-sectoral, and inter-temporal exercise, involving the interplay of many economic variables to produce an employment outcome. It requires medium to long-term planning and process. As can be seen in the table, employment in the current year is a product of a process that started two years before.

The framework indicates that employment in agriculture is positively influenced by two-year lagged employment in the non-agric sectors; two-year lagged GVA in non-agric sectors; and, negatively influenced by two-year lagged employment in agric; one-year lagged agricultural output (GVA_Agric-1); and, the previous year's wage rate. This explains the backward and the forward linkages of the agricultural sector to the other sectors of the economy through input procurement, output processing and marketing. Furthermore, production and employment expansion in the other (non-agricultural) sectors of the economy lead to improved household income and demand for food and other agricultural products which creates more opportunity for agricultural employment. It also explains the age-long conjecture of vicious cycle of production in the largely peasant agricultural sector, whereby farmers react to their prior year(s) experience on farm labour (and other input) prices, overproduction and price depression in taking current year's production (and input procurement) decisions.

Similarly, employment in the manufacturing sector is positively influenced by one-year lagged employment in administration and social services; and, one-year lagged employment in mining. On the other hand, it is negatively influenced by one-year lagged employment in agriculture; two-year lagged employment in manufacturing; one-year lagged employment in construction; one-year lagged rate of inflation; and, one-year lagged weighted average prime lending rate. Increased employment in administration and social services; and, in mining and quarrying sectors all lagged by one year's reaction time will lead to increased employment in the manufacturing sector arising from increased demand for manufactured goods, which in turn encourages investors to employ more labour to meet expanded household demand. In contrast, one-year lagged employment in agriculture and construction sectors combined to limit employment in manufacturing, probably, due to competition in the labour market, and vice versa. Employment in the manufacturing sector, also moves in the opposite direction to prior two-year employment in the same sector, probably, due to inventory build-up and depletion cycles, and the reaction time.

Furthermore, one-year lagged inflation rate inversely influences manufacturing sector employment since inflation limits the budget constraint for the procurement of production 
raw materials and the number of labour hands required to convert them to finished goods. In the same manner, one-year lagged weighted average prime lending rate (WAPLR) inversely affects employment creation in the manufacturing sector, because rising interest rate is a disincentive to investors, which, in turn, limits industrial demand for labour. The converse is equally true. In addition, investors need a one-year reaction time to decide and adjust their plans to changes in interest rate.

In the mining and quarrying sector, one-year lagged GVA in the manufacturing sector positively influenced employment because the manufactured products from that sector, like vehicles, make use of fuel, while some other manufactured products are utilised in mining and quarrying. Furthermore, the output of mining and quarrying, like crude petroleum in oil refining, constitute input into manufacturing. There exists a very strong linkage between manufacturing, and mining and quarrying. On the other hand, one-year lagged GVA in the agricultural sector; two-year lagged GVA in the construction sector; and, one-year lagged weighted average prime lending rate (WAPLR) negatively influenced employment. The negative influence of the one-year lagged agriculture sectoral output and two-year lagged construction sectoral output may be due to labour mobility and labour market dynamics, particularly in artisanal mining. The negative influence of the one-year lagged WAPLR on employment in mining and quarrying is due to the capital-intensive (hence loan-intensive) nature of commercial mining and quarrying. Rising interest rate will lead to reduced investment and activities in the mining and quarrying sector, thereby limiting the numbers of persons employed. Also, investors need a one-year reaction time to decide and adjust their plans to changes in interest rate.

In the administration and social services sector, employment creation is positively influenced by two-year lagged employment in agriculture; and, one-year lagged sectoral output (GVA) in mining and quarrying. However, previous year's level of employment in manufacturing and previous year's sectoral output (GVA) in construction reduces employment in the administration and social services sector. Two-year lagged employment in agriculture is expected to lead to enhanced agricultural income. This, in turn, enhances the demand for health services, education and other social services which will necessitate the employment of more persons. One-year lagged sectoral output in mining and quarrying will also increase corporate and household income. This will, in turn, increase the demand for social services and employment in the administration and social services sector. In contrast, previous year's employment in the manufacturing sector limits the socially-induced employment in public service. Similarly, previous year's output in the construction sector enhances private sector employment and consequently dampens socially-induced employment.

\section{Recommendations}

In the light of the above findings, the following policy recommendations are advance to assist in providing solution to the problems of unemployment in Nigeria.

The growth-employment targeting framework has brought to focus the inter-temporal and the multi-sectoral nature of the solution to the problem of unemployment in Nigeria, and the need for planning and across time and Ministries, Departments and Agencies (MDAs). 
Consequently, the following recommendation are made for effectiveness.

First, Nigeria should re-establish a Planning Commission to take charge of long-term planning for macroeconomic variables of aggregate investment, capital expenditure and, aggregate output, economic growth, employment, among others. The commission should be staffed and managed by professionals with statutory tenors extending across political regimes. The institution should be very strong and with constitutional backing, much similar to that of the Central Bank, and should handle the long-term planning of government spending and monitor its implementation. We used to have a National Planning Commission before, but its strength is suspect to the extent that its functions could reassigned to Ministries. Currently, it has been merged with the Federal Ministry of Finance to form the Federal Ministry of Finance and Planning.

Secondly, in the light of its cross-cutting responsibilities, the Commission should be supervised by the Presidency, where its functions should be integrated that of the National Economic Council, in which the sub-national governments are are also represented. This is to facilitate economic harmony, because, despite the fact that we have 812 governments, there is only one economy.

Thirdly, the planning commission should support Federal MDAs, and sub-national governments to prepare long-term strategy papers that take into account all issues relevant to long-term economic growth and employment, among others. The Commission should also work closely with the private sector to stimulate private sector investment, output and employment. The Strategy papers should be consolidated into one national strategy document that will be broken down into medium term, and short term plans on rolling basis for implementation. Since the policy outcome will depend on implementation, a very strong and professional Monitoring and Evaluation (M\&E) department should be instituted to ensure that planning and implementation achieve the objectives set out always.

\section{Conclusions}

There are two summary inferences derivable from the above framework, viz: for balanced, diversified, and inclusive growth and commensurate employment generation in the Nigerian economy during the period under review, policy formulation should have taken into consideration the components of the above framework; and, for the economy to continue to grow at that expected rate trajectory and be accompanied by diversified, inclusive, and commensurate job creation, policy makers must simultaneously take into account the issues in the above framework, their interconnectedness and the balancing of same.

In conclusion, employment (or unemployment) rate targeting is a complex web of inter-temporal and inter-sectoral activities. Rigorous planning across all the sectors of the economy is required on a medium to long-term basis, taking into account the peculiarities of the various sectors as well as the sectoral linkages, the value chains and the various reaction times to changes in policy stimuli in all the sectors of the economy. The recommendations advanced above should be deployed immediately to stem the tide of the high and ever rising unemployment in Nigeria. 


\section{Ml Macrothink}

Journal of Asian Development

ISSN 2377-9594 2021, Vol. 7, No. 1

\section{References}

Adegun, O. (2014). The Effects of Ebola Virus on the Economy of West Africa Through the Trade Channel. Journal of Humanities and Social Science. 19(10). 48-56. https://doi.org/10.9790/0837-191044856

Adeniyi, A. (2019). Economic growth and employment nexus in Nigeria's agricultural and non-agricultural sectors (1981-2014) (PhD Thesis in the Department of Agricultural Economics (in Press)).

Ajakaiye, O., Jerome, F. T., Nabena, D., \& Alaba, O. A. (2016). Understanding the Relationship Between Growth and Employment in Nigeria. Africa Growth Initiatives at Bookings. Development Policy Research Unit, United Nations University, UNU-WIDER. May. https://doi.org/10.35188/UNU-WIDER/2015/013-3

Ajilore, T., \& Yinusa, O. (2011). An Analysis of Employment Intensity of Sectoral Output Growth in Botswana. Southern Africa Business Renew, 15(2), 26-42.

Ajimotokan. O., \& Obi. P. (2016). Government and NLC set up technical committee on minimum wage and pump price of petrol. Back page, Thisday Newspaper, May 26.

Baah-Boateng, W. (2013). Determinants of Unemployment in Ghana. African Development Review, 21(4), 385-399. https://doi.org/10.1111/1467-8268.12037

Backer, D., \& Schmitt, J. (1999). The Macroeconomic roots of high unemployment: the impact of foreign growth. Economic Policy Institute. Retrieved March 3, 2013, from http://www.epinet.org

Bankole, A. S., \& Fatai, B. O. (2013). Empirical Test of Okun's Law in Nigeria. International Journal of Economic Practices and Theories, 3(3). Retrieved from www.ijept.org

Buhari, M. (2016). 27 States have difficulties paying salaries. Punch Newspapers, July 24.

Buescher \& Muller. (1999). Exchange rate Volatility Effect on the German Labour Market. Intereconomics. January.

Cauresma, J. C. (2003). Okun's Law Revisited. Oxford Bulletin of Economics and Statistics. 65(4), 439-451. https://doi.org/10.1111/1468-0084.t01-1-00056

Central Bank of Nigeria (CBN). 2015. 2014 Annual Report and Statement of Accounts.

Cobb, C. W., \& Douglas, P. H. (1928). A Theory of Production. American Economic Review, Papers and Proceedings, March, 139-65.

Cooley, T. F., \& Prescott, E. C. 1973. Systematic (Non-random) Varying Parameter Regression: A Theory and Some Applications. Annals of Economic and Social Measurement, $16,463-474$.

Dollar, D., \& Kraay, A. (2002). Growth is good for the poor. Journal of Economic growth, 7(3), 195-225. https://doi.org/10.1023/A:1020139631000 
Dopke, J. (2001). The Employment Intensity of Growth in Europe. Kieler Arbeitspapiere. No. 1021. Retrieved from http://hdl.handle.net/10419/17746

Douglas, P. H. (1948). Are There Laws of Production? American Economic Review, March. $1-41$.

Eme, O. I., \& Ugwu, S. C. (2011). Governors and the new minimum wage act: implications for state-labour relations in Nigeria. Arabian Journal of Business and Management Review, $1(3)$.

Engle, R. F., \& Granger, C. W. (1987). Co-Integration and Error Correction: Representation, Estimation and Testing. Econometrica, 55(2), 251-276. https://doi.org/10.2307/1913236

Faniran, M. (2016). Failure to pass PIB has wilted investment inflow to the oil sector. Executive Discourse by Senior Manager, Energy, 5 Accenture Nigeria, National Mirror. July 27.

Felipe, J., \& Fisher, F. M. (2003). Aggregation in Production Functions: What Applied Economists Should Know. Metroeconomica, May-September, 208-62. https://doi.org/10.1111/1467-999X.00166

Felipe, J., \& McCombie, J. S. L. (2005). How Sound Are the Foundations of the Aggregate Production Function? Eastern Economic Journal, Eastern Economic Association, 31(3), 467-488.

Felipe, J., \& McCombie, J. S. L. (2001). The CES Production Function, the Accounting Identity and Occam's Razor. Applied Economics, 12(8), 21-32. https://doi.org/10.1080/00036840122836

Felipe, J., \& McCombie, J. S. L. (2015). Aggregate Production Function and the Measurement of Technical Change 'Not Even Wrong. Edward Elgar Publishing Ltd.

Flaig, G., \& Rottman, H. (2000). Input Demand and the Short- and the Long-Run Employment Thresholds: An empirical analysis for the German manufacturing sector. CES ifo Working Paper No. 264.

Folawewo, A. O. (2015). Institutions Regulatory Framework and Labour Market Outcomes in Nigeria. Paper prepared for 10th IZA/World Bank Conference on Employment and Development, Technological change and Jobs. 4-6 June 2015, Bonn Germany.

Fox, L., Haines, C., Munoz, J. H., \& Thomas, A. (2013). Africa's Got Work to Do: Employment Prospect in the New Century. IMF working Paper WP/13/201. https://doi.org/10.5089/9781484389195.001

Hansen, P., \& King, A. (1996). The determinants of health care expenditure: A co-integration approach. Journal of Health Economics, 15(1), 127-137. https://doi.org/10.1016/0167-6296(95)00017-8

ILO. (1970). General Survey of the Reports of the Minimum Wage Fixing Convention. No. 131, and the Minimum Wage Fixing Recommendations No. 135. International Labour 
Conference, 103rd Session, 2014. ILC.103/III/1B.

IMF. (2010). Cameroon: Growth and Employment Strategy Paper (Reference Framework for Government Action Over the Period 2010-2020) Cameroon: Poverty Reduction Strategy Paper, IMF Country Report No. 10/257, Chapter 4, pp 85-92, August, 2010). https://doi.org/10.5089/9781455205752.002

Islam, I., \& Nazara, S. (2000). Estimating employment elasticity for the Indonesian economy. International Labour Office, Jakarta, Indonesia. International Labour Organisation (ILO).

Islam, R. (2004). The Nexus of Economic Growth, Employment and Poverty Reduction: An empirical analysis. Recovery and Reconstruction Department. ILO, Geneva.

Iyoha, M. A. (1978). The relation Between Employment and Growth in Developing Countries: An Econometric Analysis. Journal of Social and Economic Studies, 27(1), 69-84.

Jibril, A., Bappayaya, B., \& Babayo, H. (2015). Re-Examination of the Impact of Unemployment on Economic Growth of Nigeria: An Econometric Approach. Journal of Economics and Sustainable Development, 6(8).

Johansen, S. (1995). Likelihood-Based Inference in Co-integrated Vector Autoregressive Models. Oxford: Clarendon Press. https://doi.org/10.1093/0198774508.001.0001

Kale, Y., \& Doguwa, S. I. (2015). On the Compilation of Labour Force Statistics for Nigeria. Journal of Applied Statistics, Central Bank of Nigeria, June 6(1a).

Kapsos, S. (2005). Employment intensity of growth: trends and macroeconomic determinants. Employment Strategy Paper 2005/12. Geneva, ILO.

Kareem, R. O. (2015). Employment Level and Economic Growth of Nigeria. Journal of Sustainable Development Studies, 8(1), 53-70.

Kayode, A. et al. (2014). The rising rate of unemployment in Nigeria: the socio-economic and political implication. Global Business and Economic Research Journal, 3(1), 68-x.

Khan, A. R. (2001). Employment policies for poverty reduction. IEPDP No. 1. ILO, Geneva.

Koop, G. (2005). Analysis of Economic Data (2nd ed.). John Wiley \& Sons.

Lee, J. (2000). The robustness of Okun's Law: evidence from OECD countries. Journal of Macroeconomics, 22(2), 331-356. https://doi.org/10.1016/S0164-0704(00)00135-X

Lim, D. (1976). Export Instability and Economic Growth: A Return to Fundamentals. Oxford $\begin{array}{llll}\text { Bulletin of Economics and } & \text { Statistics, 38(4), } 325 .\end{array}$ https://doi.org/10.1111/j.1468-0084.1976.mp38004007.x

Malunda, D. (2012). Employment Intensity of Non-Agricultural Growth in Rwanda: Analysing the Links between Growth, Employment and Productivity in Rwanda. Institute of Policy Analysis and Research. Rwanda.

Mkhize, N. (2015). The Sectoral Employment Intensity of Growth in South Africa: 2000:01 - 
2012:04 (School of Economic Sciences, University of South Africa. P.O. Box 392, Pretoria, 0003. South Africa).

Nangale, G. (2012). The Role of the State in Economic Development: Employment Challenges in Eastern Africa - The case of Tanzania. A Country Paper Presentation at the Friedrich Ebert Stiftung (FES) Eastern African Conference on Employment Policies. Nairobi, Kenya. September 24 - 25.

National Centre for Economic Management and Administration (NCEMA) (a \& b). 2004. Understanding Structural Adjustment Programme in Nigeria. A Draft Report Submitted to Global Development Network. Presented at the Workshop on Understanding Reform, New Delhi, India. January 25-26.

NBS. (2014). The Comparability of GDP Growth Rates Pre- and Post-Rebasing. Retrieved from nigeriansta.gov.ng

NBS. (2015). Nigerian Gross Domestic Product Report, Quarter Two. Issue 6.

NBS. (2015). Unemployment / Under-employment Watch.

NBS. (2016). Post GDP Rebasing Revision 1981 - 2010. July 18.

NBS. (2019). Consumer Price Index February, 2019. March.

Nigeria Employers' Consultative Association (NECA). (2003). Inter Industrial Survey.

Njoku, A., \& Ihugba, O. A. (2011). Unemployment and Nigerian Economic Growth (1985-2009). Proceedings of the 2011 Conference on Teaching, Learning, and Change. International Association of Teaching and Learning (IATEL).

Nwagbara, E. N. (2011). The Story of Structural Adjustment Programme in Nigeria from the Perspective of Organised Labour. Australian Journal of Business and Management Research. 1(7), 30-41.

Odia, J. O., \& Okoye, A. E. (2012). Pension Reforms in Nigeria: A Comparison Between the Old and the New Scheme. Afro Asia Journal of Social Sciences, 3(1), Quarter 1.

Ogbimi, F. E. (2016). Structural Adjustment is the Wrong Policy. African Technology Forum, $8(1)$.

Ogbonna, B. C. (2012). Structural Adjustment Programme (SAP) in Nigeria: An Empirical Assessment. Journal of Banking, 6(1), 19-40.

Ogwumike, F. O., Alaba, F., Alaba, O., Alayande, B., \& Okojie, E. (2006). Labour Force Participation, Earnings and Inequality in Nigeria. African Economic Research Consortium. Retreived from www.aercafrica.org

Okun, A. (1962). Potential output: its measurement and significance. Proceedings of the Business and Economic Statistics Section of the American Statistical Society. 
Okun, A. (1970). Potential GDP: its Measurement and Significance. In: Okun, A. (ed.), The Political Economy of Prosperity. Washington DC.

Oloni, E. F. (2013). The Impact of Economic Growth on Employment in Nigeria. Journal of International Business and Management, 6(1), 113-119.

Omolo, J. (2010). The Dynamics and Trends of Employment in Kenya. Institute of Economic Affairs, Kenya. IEA Research Paper Series No1.

Page, J. (2012). Youth, Jobs, and Structural Change: Confronting Africa's "Employment Problem" Working Paper No. 155, October. Prepared for the African Development Bank. Office of the Chief Economist.

Pini, P. (1997). Occupazione, tecnologia e crescita: modelli interpretativi ed evidenze empiriche a livello macroeconomico. Paper presented at conference of Accademia Nazionale dei Lincei on 'Svillupo technologico e disoccupazion: transfromazione della societa', Rome, 16-18 January.

Phillip, A. W. (1958). The Relation Between Unemployment and the Rate of Change of Money Wage Rates in the United Kingdom, 1861-1957. Economica. 25(100), 283-299. https://doi.org/10.2307/2550759

Prachowny, \& Martin, F. J. (1993). Okun's Law: Theoretical Foundations and Revised Estimates. The Review of Economics and Statistics, 75(2), 331-336. https://doi.org/10.2307/2109440

PriceWaterCoopers, (2015). Economic and Fiscal Implications of Nigeria's Rebased GDP. Available at pwc.com.

Ravallion, M. 2001. What is needed for a more pro-poor growth process in India? Economic and Political Weekly. 35(13).

Ravallion, M., \& Chen, S. (1997). What can new survey data tell us about recent changes in distribution and poverty?. World Bank Economic Review, 11(2), 357-382. https://doi.org/10.1093/wber/11.2.357

Revenga, A. L., \& Bentolila, S. (1995). What Affects Employment Intensity of Growth. Discussion Paper No 9517, Bank of Spain.

Sanchez-Puerta, M. L. S. (2010). Labour Market Policy Research for Developing Countries: Recent Examples from the Literature. What Do we Know and What Should we Know? Social Protection and Labour, the World Bank, SP Discussion paper No 1001.

Sawtelle, B. (2007). Analysing the link between real GDP and employment: an industry sector approach. Business Economics, 42, 46-54. https://doi.org/10.2145/20070405

Silvapulle, P., Moosa, I. A., \& Silvapulle, M. J. (2004). Asymmetry of Okun's Law. Canadian Journal of Economics, 37, 353-374. https://doi.org/10.1111/j.0008-4085.2004.00006.x

Silverstone, B., \& Harris, R. (2001). Testing for Asymmetry in Okun's Law: A cross-Country 


\section{Macrothink}

Journal of Asian Development

ISSN 2377-9594 2021, Vol. 7, No. 1

Comparison. Economics Bulletin, 5(2), 1-13.

Siphambe, H. K. (2007). Growth and Employment Dynamics in Botswana: A case study of policy coherence. Policy Integration and Statistics Department, International Labour Office. Working Paper, 82. October.

Sodipe, O. A., \& Ogunrinola, O. I. (2011). Employment and Economic Growth Nexus in Nigeria. International Journal of Business and Social Science, 2(11).

Solow, R. M. (1966). Review of Capital and Growth. American Economic Review. December, 1257-60.

Soludo, C. C. (2015). PDP handed Nigeria over in a better state than it met Nigeria. The Whistler, December 20.

Song, H., \& Witt, S. F. (2000). Tourism demand modelling and forecasting. Modern econometric approaches. Oxford, Pergamon.

Soto, R. (2009). Dollarisation, Economic Growth and Employment. Economic Letters, 105(1), 42-45. https://doi.org/10.1016/j.econlet.2009.05.012

Stock, J. H., \& Watson, M. W. (2017). Introduction to Econometrics (3rd ed.). Pearson Education.

Tackie, N. O., \& Abhulimen, O. S. (2002). Impact of the Structural Adjustment Program on the Agricultural Sector and Economy of Nigeria. Journal of Finance and Economic Development, 5(2), 1-25.

Temitope, L.A.L. (2013). Does Economic Growth Lead Employment in South Africa? Journal of Economics and Behavioural Studies. 5(6), 336-345. https://doi.org/10.22610/jebs.v5i6.409

Temitope, L.A.L. 2014. Empirical Analysis of Employment Elasticity of Growth in Botswana. Mediterranean Journal of Social Science. 5(2) :171-180.

Triechel, V. (2010). Putting Nigeria Back to Work: A strategy for Employment and Growth IBRD / World Bank, Washington, D C 20433. https://doi.org/10.1596/978-0-8213-8072-7

Viren, M. (2001). The Okun's Curve is non-linear. Economic Letters, 70, 253-257. https://doi.org/10.1016/S0165-1765(00)00370-0

Walters, A. A. (1963). Production and Cost Functions: An Econometric Survey. Econometrica, January-April. 1-66. https://doi.org/10.2307/1910949

Wan, H. Y. (1971). Economic Growth. New York: Harcourt Brace Jovanovich.

Yogo, T. (2008). Growth and Employment in Sub-Sahara Africa: Theoretical Evidence and Empirical Facts. Retrieved from http://mpra.ub.uni-muenchen.de/10474/ MPRA Paper No10474. 


\section{Macrothink}

\section{Appendixes}

Appendix 1. Employment in agriculture sector

\begin{tabular}{|c|c|c|c|c|c|c|}
\hline & Scenario1 & Scenario2 & Scenario3 & Scenario4 & Scenario5 & Scenario6 \\
\hline & Coef. (z) & Coef.(z) & Coef.(z) & Coef.(z) & Coef.(z) & Coef.(z) \\
\hline $\mathrm{Ce} 1$ & $2.45(1.34)$ & $0.128(2.99)^{* * *}$ & $-3.135(-0.79)$ & $-1.252(-3.34) * * *$ & - & $-0.0611(-0.39)$ \\
\hline $\mathrm{Ce} 2$ & $-2.07(-2.13) * *$ & $-0.114(-2.62) * * *$ & $3.328(1.11)$ & $-0.986(-3.72) * * *$ & - & $0.009(0.33)$ \\
\hline $\mathrm{Ce} 3$ & $-.497(-0.65)$ & $0.275(2.95)^{* * *}$ & $-0.416(-1.26)$ & $2.133(3.56)^{* * *}$ & - & $0.141(0.43)$ \\
\hline $\mathrm{Ce} 4$ & & $-0.119(-3.08) * * *$ & - & - & - & - \\
\hline Employment Agriculture(-1) & $0.11(0.08)$ & $-0.705(-2.26)^{* *}$ & $-2.678(-1.24)$ & - & - & - \\
\hline Employment Agriculture(-2) & $-1.94(-2.08)^{* *}$ & $0.156(0.36)$ & $-0.497(-0.49)$ & - & - & $-0.171(-0.3)$ \\
\hline Employment Mining(-1) & - & $-0.449(-1.22)$ & - & - & - & $-0.29(-0.73)$ \\
\hline Employment Mining(-2) & - & $-0.309(-0.74)$ & - & - & - & $-0.038(-0.06)$ \\
\hline Employment Manufacturing (-1) & - & $-0.112(-0.67)$ & - & - & - & $-0.734(-1.33)$ \\
\hline Employment Manufacturing (-2) & - & $-0.354(-1.97)^{* *}$ & - & - & - & $-0.006(-0.02)$ \\
\hline Employment Construction(-1) & - & $0.081(0.17)$ & - & - & - & $-0.012(-0.03)$ \\
\hline Employment Construction(-2) & - & $-0.649(-1.54)$ & - & - & - & $-0.122(-0.16)$ \\
\hline Employment Admin(-1) & - & $-0.027(-0.07)$ & - & - & - & $0.074(0.12)$ \\
\hline Employment Admin(-2) & - & $0.913(2.30)^{* *}$ & - & - & - & $-0.06(-0.56)$ \\
\hline Employment Trade & - & - & - & - & - & $0.051(0.62)$ \\
\hline Employment Non-agric(-1) & $-0.25(-0.35)$ & - & - & - & - & - \\
\hline Employment Non-agric(-2) & $1.15(2.23)^{* *}$ & - & - & - & - & - \\
\hline GVA Agriculture(-1) & $-0.13(-2.10)^{* *}$ & $-0.0653(-1.98)^{* *}$ & - & - & - & - \\
\hline GVA Agriculture(-2) & $0.018(0.34)$ & $0.0356(0.96)$ & - & $1.18(3.75)^{* * *}$ & - & $-0.06(-0.56)$ \\
\hline GVA Mining(-1) & - & $0.115(1.98)^{* *}$ & $1.219(1.23)$ & $0.561(2.29)^{* *}$ & - & $0.051(0.62)$ \\
\hline GVA Mining(-2) & - & $0.126(3.54) * * *$ & $0.843(0.90)$ & $-0.184(-0.51)$ & - & $0.014(0.17)$ \\
\hline GVA Manufacturing (-1) & - & $-0.022(-0.6)$ & $0.089(0.09)$ & $-0.205(-0.8)$ & - & $0.107(1.26)$ \\
\hline GVA Manufacturing (-2) & - & $-0.069(-1.91)^{*}$ & $-0.332(-0.55)$ & $-0.252(-0.56)$ & - & $-0.0005(-0.01)$ \\
\hline GVA Construction(-1) & - & $-0.003(-0.10)$ & $-2.303(-0.94)$ & $-0.538(-2.82)^{* * *}$ & - & $-0.003(0.09)$ \\
\hline GVA Construction(-2) & - & $-0.14(-2.80)^{* * *}$ & $-1.589(-0.90)$ & $0.757(3.77) * * *$ & - & $-0.016(-0.18)$ \\
\hline GVA Admin (-1) & - & $0.64(3.83)^{* * *}$ & $0.974(0.92)$ & $0.506(2.33) * *$ & - & $-0.023(-0.46)$ \\
\hline GVA Admin $(-2)$ & - & $0.48(4.31)^{* * *}$ & $1.492(1.34)$ & $-1.405(-2.61) * * *$ & - & $0.177(0.54)$ \\
\hline GVA Trade & - & - & - & $-2.669(-4.23) * * *$ & - & $0.259(0.9)$ \\
\hline GVA Non-agric(-1) & $0.085(0.70)$ & - & - & - & - & - \\
\hline GVA Non-agric(-2) & $0.39(2.59)^{* *}$ & - & - & - & - & - \\
\hline GDP & - & - & - & - & - & - \\
\hline Inflation Rate(-1) & $-0.002(-0.34)$ & - & $-0.008(-0.72)$ & - & - & - \\
\hline Inflation Rate(-2) & $0.008(1.21)$ & - & $-0.001(-0.18)$ & - & - & - \\
\hline WAPLR(Weighted Average Prime Lending Rate)(-1) & $-0.03(-1.56)$ & - & $-0.052(-1.25)$ & $-0.008(-0.42)$ & - & $-0.0008(-0.11)$ \\
\hline WAPLR(Weighted Average Prime Lending Rate)(-2) & $-0.011(-0.67)$ & - & $-0.037(-1.22)$ & $-0.0002(-0.01)$ & - & $0.006(0.83)$ \\
\hline Minimum wage $(-1)$ & $-0.023(-2.10)^{* *}$ & - & $-0.007(0.98)$ & $0.556(3.47)^{* * *}$ & - & - \\
\hline Minimum wage (-2) & $-0.009(-1.06)$ & - & $-0.001(-0.11)$ & $0.147(1.51)$ & - & - \\
\hline Constant & $0.04(2.68)^{* * *}$ & $0.002(-0.13)$ & $0.009(0.44)$ & $-0.062(-1.38)$ & - & - \\
\hline
\end{tabular}

Source: Author's Analysis of Data collected from the National Bureau of Statistic 


\section{MInstitute Machin $_{\text {Int }}$}

Journal of Asian Development

ISSN 2377-9594

2021, Vol. 7, No. 1

Appendix 2. Employment in mining and quarrying sector

\begin{tabular}{|c|c|c|c|c|c|c|}
\hline & Scenario1 & Scenario2 & Scenario3 & Scenario4 & Scenario5 & Scenario6 \\
\hline & Coef.(z) & Coef.(z) & Coef.(z) & Coef.(z) & Coef.(z) & Coef.(z) \\
\hline $\mathrm{Ce} 1$ & - & $0.037(0.52)$ & $-1.911(-0.7)$ & $0.081(0.21)$ & - & $-0.138(-1.02)$ \\
\hline $\mathrm{Ce} 2$ & - & $0.038(0.48)$ & $-1.395(-0.67)$ & $1.096(3.99) * * *$ & - & $0.03(1.31)$ \\
\hline $\mathrm{Ce} 3$ & - & $-0.114(-1.57)$ & $0.413(1.81)^{*}$ & $-1.624(-2.62)^{* * *}$ & - & $0.173(0.61)$ \\
\hline $\mathrm{Ce} 4$ & - & $0.056(0.36)$ & - & - & - & - \\
\hline $\mathrm{Ce} 5$ & - & $-0.065(-1.00)$ & - & - & - & - \\
\hline Employment Agriculture(-1) & - & $0.433(0.83)$ & $1.969(1.31)$ & - & - & $-0.013(-0.03)$ \\
\hline Employment Agriculture(-2) & - & $0.824(1.15)$ & $0.812(1.15)$ & - & - & $-0.563(0.1)$ \\
\hline Employment Mining(-1) & - & $0.096(0.16)$ & $-0.603(-0.88)$ & - & - & $0.159(0.27)$ \\
\hline Employment Mining(-2) & - & $1.391(2)^{* *}$ & $-0.267(-0.41)$ & - & - & $0.305(0.64)$ \\
\hline Employment Manufacturing (-1) & - & $0.428(1.53)$ & $-1.07(-1.59)$ & - & - & $0.475(1.49)$ \\
\hline Employment Manufacturing (-2) & - & $0.268(0.89)$ & $-0.206(-0.50)$ & - & - & $-0.321(-0.8)$ \\
\hline Employment Construction(-1) & - & $0.198(0.25)$ & $-1.606(-0.94)$ & - & - & $0.62(0.93)$ \\
\hline Employment Construction(-2) & - & $-0.750(-1.07)$ & $-0.01(-0.01)$ & - & - & $-0.392(-0.75)$ \\
\hline Employment Admin(-1) & - & $0.155(0.23)$ & $0.708(0.96)$ & - & - & $-0.579(-1.02)$ \\
\hline Employment Admin(-2) & - & $1.272(1.91)^{*}$ & $0.151(0.2)$ & - & - & $0.743(1.37)$ \\
\hline Employment Trade & - & - & - & - & - & - \\
\hline Employment Non-agric(-1) & - & - & - & - & - & - \\
\hline Employment Non-agric(-2) & - & - & - & - & - & - \\
\hline GVA Agriculture(-1) & - & $0.022(0.41)$ & - & $-0.891(-2.73)^{* * *}$ & - & $0.039(0.43)$ \\
\hline GVA Agriculture(-2) & - & $-0.104(-1.69)^{*}$ & - & $-0.285(-1.12)$ & - & $0.05(0.71)$ \\
\hline GVA Mining(-1) & - & $0.009(0.09)^{*}$ & - & $-0.069(-0.18)$ & - & $-0.154(-2.2)^{* *}$ \\
\hline GVA Mining(-2) & - & $-0.043(-0.73)$ & - & $0.206(0.77)$ & - & $-0.064(-0.88)$ \\
\hline GVA Manufacturing (-1) & - & $-0.062(-1.04)$ & - & $1.241(2.67)^{* * *}$ & - & $0.064(1.79)$ \\
\hline GVA Manufacturing (-2) & - & $-0.076(-1.26)$ & - & $0.566(2.87) * * *$ & - & $0.029(0.96)$ \\
\hline GVA Construction(-1) & - & $0.068(1.49)$ & - & $-0.166(-0.8)$ & - & $0.042(0.55)$ \\
\hline GVA Construction $(-2)$ & - & $-0.102(-1.2)$ & - & $-0.447(-1.99) * *$ & - & $0.079(1.8)$ \\
\hline GVA Admin (-1) & - & $-0.292(-1.04)$ & - & $0.909(1.63)$ & - & $0.152(0.54)$ \\
\hline GVA Admin (-2) & - & $-0.234(-1.27)$ & - & $0.571(0.87)$ & - & $-0.025(-0.1)$ \\
\hline GVA Trade & - & - & - & - & - & - \\
\hline GVA Non-agric $(-1)$ & - & - & - & - & - & - \\
\hline GVA Non-agric (-2) & - & - & - & - & - & - \\
\hline $\operatorname{GDP}(-1)$ & - & - & - & - & - & - \\
\hline $\operatorname{GDP}(-2)$ & - & - & - & - & - & - \\
\hline Inflation Rate(-1) & - & - & $-0.004(-0.51)$ & $0.0002(0.01)$ & - & $-0.007(-1.22)$ \\
\hline Inflation Rate(-2) & - & - & $-0.002(-0.46)$ & $0.007(0.36)$ & - & $-0.008(-1.36)$ \\
\hline WAPLR(Weighted Average Prime Lending Rate)(-1) & - & - & $-0.018(-0.65)$ & $-0.468(-2.82)^{* * *}$ & - & - \\
\hline WAPLR(Weighted Average Prime Lending Rate)(-2) & - & - & $-0.002(-0.11)$ & $-0.166(-1.65)$ & - & - \\
\hline Minimum wage $(-1)$ & - & - & $-0.009(-1.79)^{*}$ & $0.07(1.49)$ & - & - \\
\hline Minimum wage $(-2)$ & - & - & $-0.006(-0.99)$ & $-0.021(-0.60)$ & - & - \\
\hline Constant & - & $0.012(0.53)$ & $-0.016(-1.21)$ & $-0.01(-0.21)$ & - & $-0.011(-0.98)$ \\
\hline
\end{tabular}

Source: Author's Analysis of Data collected from the National Bureau of Statistics. 


\section{Appendix 3. Employment in manufacturing sector}

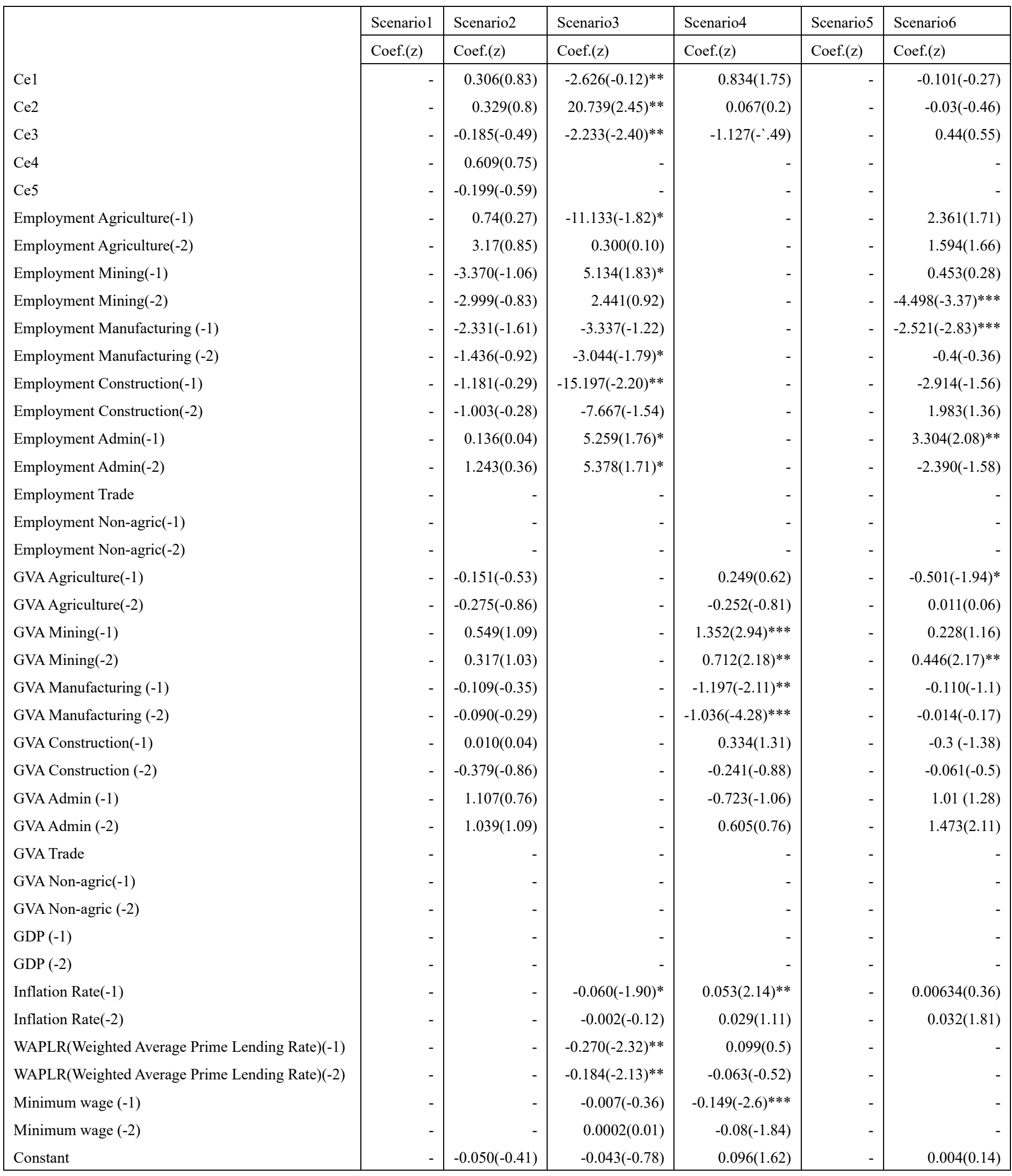

Source: Author's Analysis of Data collected from the National Bureau of Statistics 


\section{Appendix 4. Employment in construction sector}

\begin{tabular}{|c|c|c|c|c|c|c|}
\hline & Scenario1 & Scenario2 & Scenario3 & Scenario4 & Scenario5 & Scenario6 \\
\hline & Coef.(z) & Coef.(z) & Coef.(z) & Coef.(z) & Coef.(z) & Coef.(z) \\
\hline $\mathrm{Ce} 1$ & - & $0.079(0.74)$ & $2.136(0.79)$ & $0.790(2.94)^{* * *}$ & - & $-0.208(-1.26)$ \\
\hline $\mathrm{Ce} 2$ & - & $0.108(0.92)$ & $-2.761(-1.34)$ & $-0.104(-0.55)$ & - & $0.04(1.4)$ \\
\hline $\mathrm{Ce} 3$ & - & $-0.153(-1.41)$ & $0.372(1.67)$ & $-0.194(-0.45)$ & - & $0.308(0.89)$ \\
\hline $\mathrm{Ce} 4$ & - & $0.234(1.01)$ & - & - & - & - \\
\hline $\mathrm{Ce} 5$ & - & $-0.160(-1.65)$ & - & - & - & - \\
\hline Employment Agriculture(-1) & - & $0.483(0.62)$ & $1.473(0.99)$ & - & - & $0.163(0.27)$ \\
\hline Employment Agriculture(-2) & - & $0.784(0.73)$ & $-0.058(-0.08)$ & - & - & $-0.620(-1.49)$ \\
\hline Employment Mining(-1) & - & $0.874(0.95)$ & $-0.188(-0.28)$ & - & - & $0.866(1.22)$ \\
\hline Employment Mining(-2) & - & $2.049(1.98)^{* *}$ & $-0.610(-0.95)$ & - & - & $0.898(1.55)$ \\
\hline Employment Manufacturing (-1) & - & $0.054(0.13)$ & $0.273(0.41)$ & - & - & $0.155(0.4)$ \\
\hline Employment Manufacturing (-2) & - & $-0.09(-0.22)$ & $0.561(1.36)$ & - & - & $-0.42(-0.86)$ \\
\hline Employment Construction(-1) & - & $-0.197(-0.17)$ & $1.682(1)$ & - & - & $0.225(0.28)$ \\
\hline Employment Construction(-2) & - & $-1.280(-1.22)$ & $0.959(0.79)$ & - & - & $-0.734(-1.15)$ \\
\hline Employment Admin(-1) & - & $0.119(0.12)$ & $-0.192(-0.26)$ & - & - & $-0.422(-0.61)$ \\
\hline Employment Admin(-2) & - & $1.767(1.78)$ & $-0.374(-0.49)$ & - & - & $0.976(1.01)$ \\
\hline Employment Trade & - & - & - & - & - & - \\
\hline Employment Non-agric(-1) & - & - & - & - & - & - \\
\hline Employment Non-agric(-2) & - & - & - & - & - & - \\
\hline GVA Agriculture(-1) & - & $0.099(1.21)$ & - & $-0.188(-0.83)$ & - & $0.125(1.12)$ \\
\hline GVA Agriculture(-2) & - & $-0.018(-0.19)$ & - & $-0.29(-1.65)$ & - & $0.087(1.01)$ \\
\hline GVA Mining(-1) & - & $0.053(0.37)$ & - & $0.095(0.37)$ & - & $-0.096(-1.13)$ \\
\hline GVA Mining(-2) & - & $-0.028(-0.32)$ & - & $0.051(0.28)$ & - & $-0.05(-0.56)$ \\
\hline GVA Manufacturing (-1) & - & $-0.057(-0.64)$ & - & $-0.227(-0.71)$ & - & $0.037(0.86)$ \\
\hline GVA Manufacturing (-2) & - & $-0.106(-1.19)$ & - & $0.203(1.49)$ & - & $0.006(0.16)$ \\
\hline GVA Construction(-1) & - & $0.079(1.16)$ & - & $-0.137(-0.96)$ & - & $0.058(0.61)$ \\
\hline GVA Construction (-2) & - & $-0.153(-1.21)$ & - & $-0.007(-0.05)$ & - & $0.059(1.1)$ \\
\hline GVA Admin (-1) & - & $0.021(0.05)$ & - & $1.153(2.99)^{* * *}$ & - & $0.081(0.24)$ \\
\hline GVA Admin (-2) & - & $-0.095(-0.35)$ & - & $0.814(1.80)$ & - & $-0.066(-0.22)$ \\
\hline GVA Trade & - & - & - & - & - & - \\
\hline GVA Non-agric(-1) & - & - & - & - & - & - \\
\hline GVA Non-agric (-2) & - & - & - & - & - & - \\
\hline GDP $(-1)$ & - & - & - & - & - & - \\
\hline $\operatorname{GDP}(-2)$ & - & - & - & - & - & - \\
\hline Inflation Rate(-1) & - & - & $0.006(-0.78)$ & $0.006(0.49)$ & - & $-0.008(-1.03)$ \\
\hline Inflation Rate(-2) & - & - & $0.002(0.59)$ & $-0.009(-0.62)$ & - & $-0.009(-1.19)$ \\
\hline WAPLR(Weighted Average Prime Lending Rate)(-1) & - & - & $0.022(0.79)$ & $0.055(0.48)$ & - & - \\
\hline WAPLR(Weighted Average Prime Lending Rate)(-2) & - & - & $0.02(0.97)$ & $0.069(0.99)$ & - & - \\
\hline Minimum wage (-1) & - & - & $-0.015(-2.98)^{* * *}$ & $-0.029(-0.92)$ & - & - \\
\hline Minimum wage (-2) & - & - & $-0.0007(-0.11)$ & $-0.010(-0.43)$ & - & - \\
\hline Constant & - & $0.031(0.89)$ & $0.009(0.73)$ & $-0.025(-0.75)$ & - & $-0.007(-0.53)$ \\
\hline
\end{tabular}

Source: Author's Analysis of Data collected from the National Bureau of Statistics 


\section{Appendix 5. Employment in administration and social services sector}

\begin{tabular}{|c|c|c|c|c|c|c|}
\hline & Scenario 1 & Scenario2 & Scenario3 & Scenario4 & Scenario5 & Scenario6 \\
\hline & Coef.(z) & Coef.(z) & Coef.(z) & Coef.(z) & Coef.(z) & Coef.(z) \\
\hline $\mathrm{Ce} 1$ & - & $0.308(2.08)^{* *}$ & $-6.349(-1.31)$ & $-0.302(-1.04)$ & - & $-0.241(-0.98)$ \\
\hline $\mathrm{Ce} 2$ & - & $0.359(2.18)^{* *}$ & $5.077(1.38)$ & $-0.21(-1.02)$ & - & $0.039(0.93)$ \\
\hline $\mathrm{Ce} 3$ & - & $-0.304(-2.02)^{* *}$ & $-0.425(-1.05)$ & $0.465(1)$ & - & $0.401(0.78)$ \\
\hline Ce4 & - & $0.702(2.17)^{* *}$ & - & - & - & - \\
\hline $\mathrm{Ce} 5$ & - & $-0.332(-2.46)^{* *}$ & - & - & - & \\
\hline Employment Agriculture(-1) & - & $0.344(0.32)$ & $-3.294(-1.24)$ & - & - & $1.236(1.39)$ \\
\hline Employment Agriculture(-2) & - & $2.584(1.73)^{*}$ & $-0.221(-0.18)$ & - & - & $0.841(1.36)$ \\
\hline Employment Mining(-1) & - & $-1.045(-0.82)$ & $0.887(0.73)$ & - & - & $0.757(0.72)$ \\
\hline Employment Mining(-2) & - & $0.444(0.31)$ & $-0.343(-0.3)$ & - & - & $-0.349(-0.41)$ \\
\hline Employment Manufacturing (-1) & - & $-1.194(-2.05)^{* *}$ & $-0.6(-0.5)$ & - & - & $-1.195(-2.08)^{* *}$ \\
\hline Employment Manufacturing (-2) & - & $-1.112(-0.76)$ & $-0.292(-0.40)$ & - & - & $-0.86(-1.19)$ \\
\hline Employment Construction(-1) & - & $0.027(0.02)$ & $-2.3(-0.77)$ & - & - & $-1.177(-0.98)$ \\
\hline Employment Construction(-2) & - & $-1.112(-0.76)$ & $-0.874(-0.40)$ & - & - & $-0.484(-0.51)$ \\
\hline Employment Admin(-1) & - & $-0.796(-0.57)$ & $0.573(0.44)$ & - & - & $0.790(0.77)$ \\
\hline Employment Admin(-2) & - & $1.742(1.26)$ & $0.694(0.51)$ & - & - & $0.44(0.45)$ \\
\hline Employment Trade & - & - & - & - & - & \\
\hline Employment Non-agric(-1) & - & - & - & - & - & - \\
\hline Employment Non-agric(-2) & - & - & - & - & - & - \\
\hline GVA Agriculture(-1) & - & $-0.007(-0.07)$ & - & $0.101(0.42)$ & - & $0.014(0.09)$ \\
\hline GVA Agriculture(-2) & - & $-0.098(-0.77)$ & - & $0.249(1.31)$ & - & $0.072(0.56)$ \\
\hline GVA Mining(-1) & - & $0.423(2.09)^{* *}$ & - & $-0.076(-0.27)$ & - & $-0.046(-0.37)$ \\
\hline GVA Mining(-2) & - & $0.216(1.75)$ & - & $-0.162(-0.81)$ & - & $0.091(0.69)$ \\
\hline GVA Manufacturing (-1) & - & $-0.133(-1.07)$ & - & $0.028(0.8)$ & - & $0.011(0.18)$ \\
\hline GVA Manufacturing (-2) & - & $-0.190(-1.52)$ & - & $-0.034(-0.23)$ & - & $0.039(0.71)$ \\
\hline GVA Construction(-1) & - & $0.077(0.81)$ & - & $0.09(0.58)$ & - & $-0.023(-0.17)$ \\
\hline GVA Construction (-2) & - & $\begin{array}{r}-0.396(-2.24) \\
* *\end{array}$ & - & $0.227(1.35)$ & - & $0.046(0.58)$ \\
\hline GVA Admin (-1) & - & $0.695(1.19)$ & - & $-0.112(-0.27)$ & - & $0.194(0.38)$ \\
\hline GVA Admin (-2) & - & $0.496(1.29)$ & - & $-0.594(-1.21)$ & - & $0.285(0.63)$ \\
\hline GVA Trade & - & - & - & - & - & - \\
\hline GVA Non-agric(-1) & - & - & - & - & - & - \\
\hline GVA Non-agric (-2) & - & - & - & - & - & - \\
\hline $\operatorname{GDP}(-1)$ & - & - & - & - & - & - \\
\hline GDP $(-2)$ & - & - & - & - & - & \\
\hline Inflation Rate(-1) & - & - & $-0.02(-1.47)$ & $-0.004(-0.32)$ & - & $-0.009(-0.87)$ \\
\hline Inflation Rate(-2) & - & - & $-0.005(-0.67)$ & $-0.011(-0.71)$ & - & $0.0005(0.05)$ \\
\hline WAPLR(Weighted Average Prime Lending Rate)(-1) & - & - & $-0.047(-0.94)$ & $0.086(0.69)$ & - & - \\
\hline WAPLR(Weighted Average Prime Lending Rate)(-2) & - & - & $-0.024(-0.65)$ & $0.031(0.42)$ & - & - \\
\hline Minimum wage (-1) & - & - & $-0.025(-2.77)^{* * *}$ & $-0.023(-0.67)$ & - & - \\
\hline Minimum wage (-2) & - & - & $-0.005(-0.45)$ & $0.015(0.59)$ & - & - \\
\hline Constant & - & $-0.027(-0.57)$ & $0.013(0.57)$ & $0.089(2.46)^{* *}$ & - & $0.001(0.06)$ \\
\hline
\end{tabular}

Source: Author's Analysis of Data collected from the National Bureau of Statistics 


\section{Appendix 6: Employment-Growth targeting:} Extracts from VECM

(+)E_NonAgri-2/ GVA

NonAgri-2

(-) E_Agri-2/

GVA_Agri-1/

WageRate-1

(+) E_Admin-1/

E_Mining-1

(-) E_Agric-1/

E_Man'g-2/E_Const-1/

Inflation-1/ WAPLR-1

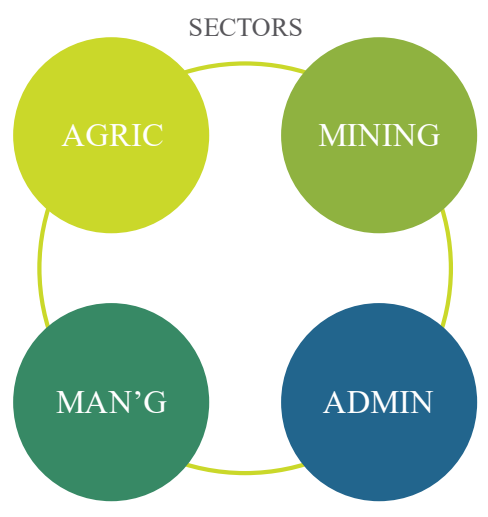

(+) GVA_Man'g-1

(-) GVA_Agri-1/

GVA_Const - 2/

WAPLR - 1

(+) E_Agri - 2/

GVA_Min - 1

(-) E_Man'g - 1/

GVA_Const - 1

\section{Copyright Disclaimer}

Copyright for this article is retained by the author(s), with first publication rights granted to the journal.

This is an open-access article distributed under the terms and conditions of the Creative Commons Attribution license (http://creativecommons.org/licenses/by/4.0/). 